\title{
Evaluation of the physical, mechanical and kinetic properties of some cereals and leguminous seeds in Benin republic
}

\author{
E. D. Dayou ${ }^{1,2}$, K. L. B. Zokpodo ${ }^{1}$, A. L. R. Glele Kakaï ${ }^{2}$ \\ ${ }^{I}$ School of Environmental Management, Faculty of Agronomic Sciences, University Of Abomey-Calavi 01 BP 526 Cotonou, BENIN \\ ${ }^{2}$ Laboratory of Biomathematics and Forestry Estimations, Faculty of Agronomic Sciences, University of Abomey-Calavi 04 BP 1525 Cotonou, BENIN \\ "Corresponding Author: phreddoss1@yahoo.fr
}

\begin{abstract}
In order to design a seeder for direct sowing, a seed characterization study was conducted. The objective was to assess the physical, mechanical and kinetic properties of the most cultivated cereals and leguminous in Benin. Two varieties of Zea mays, four varieties of Vigna unguiculata, one variety of Arachis hypogea, one variety of Cajanus cajan and two varieties of Glycine maxwere studied. It was noticeda variation in physical parameters not only between species but also between varieties of the same species. All sphericity coefficients are greater than 0.7 with C.cajan which is more spherical $(0.91 \pm 0.03)$ against the DMR ESR-W/QPM and 85 TZSR-W varieties of Z.mays which are the least spherical with $0.72 \pm 0.10$ and $0.71 \pm 0.11$ respectively. The rupture force generally increased from 14 to $720 \mathrm{~N}$. Vigna TVX 32-36 is the most resistant with $633.3 \pm 75.72 \mathrm{~N}$ against $16.0 \pm 2.0$ $\mathrm{N}$ for Arachis TS32-1 the least resistant. Overall, the falling speed decreased from 1.67 to $0 \mathrm{~m} / \mathrm{s}$ on the rigid PVC, from 1.36 to 0 $\mathrm{m} / \mathrm{s}$ on the black plate and from 1.67 to $0 \mathrm{~m} / \mathrm{s}$ on the transparent hose when the angle of inclination increases from $20^{\circ}$ to $70^{\circ}$ relative to vertical. These parameters are essential for good sizing of the distribution system and the seed descent channels for a seeder.They can also be used for grains calibration and other use in agricultural engineering and food processing.
\end{abstract}

Keywords: Seeds, physical properties, mechanical properties, kinetic properties, Benin

DOI: http://dx.doi.org/10.4314/ijest.v11i1.4

\section{Introduction}

Agriculture is important for African development. Subsistence agriculture is practiced by a majority of small farmers, yield differentials are profound and soil poverty and other constraints add to the difficulty in sustainable agriculture practices and difficulty to create income (FAO, 2015). Africa is the center of origin and a major producer of various cereals such as maize, sorghum, african rice (Macauley and Ramadjita, 2015) and leguminous crops such as cowpea, groundnuts and soybeans (IRAD, 2013). While cereals are staple foods for the majority of the population, leguminous could be an alternative to improve the nitrogen nutrition of humans and animals and for plant nutrient management which is environmentally safe and can efficiently reduce the fertilizer consumption in the developing countries (Pokhrel and Pokhrel, 2013).

In order to increase production, mechanization of production systems with respect the environment is necessary. For this purpose, the use of rapid technologies such as seeders appears necessary. Indeed, mechanical sowing contributes to the speed of the work and the good development of the crops (Azmon, 2013). It is done either with a conventional seeder or with a direct seeder. Whether done in conventional or direct sowing, the seed must be placed at a good depth and covered carefully. However, apart from the low germination rate sometimes attributable to poor seeding depth and seed recovery (Massicotte et al., 2000), problems related to the distribution systems, namely the presence of two seeds per hole,fracture and lack of seeds on the line are also noticed. The severity of these problems is sometimes high and requires the farmer to monitor very intensively the field after sowing (Tits and Leveque, 2001). To remedy this, seed calibration have been created. However, these sizes are not the same for all countries and for varieties of the same species. 
In Benin, the availability of certified seeds is not always effective, forcing producers to turn to previous harvests or sold on the market (Raunet, 2002) and whose physical, mechanical and kinetic properties are not known. For certified seeds, their calibration is not often uniform. Some seed producers continue to use rudimentary equipment, despite the availability of modern calibration equipment (Achigan-Dako et al., 2014). This distorts the calibration and constitutes a constraint for the design of agricultural equipment. However, it is not possible to design and produce efficient equipment without a thorough knowledge of the physical and mechanical properties of the seeds because their efficiency and performance depend of them (Ahouansou et al., 2012; Faleye et al., 2013). In fact, beyond the opening and closing systems of the grooves, the characteristics of the seed distribution and descent systems constitute another technical aspect on the seeder. Thus, the physical parameters of the seeds (length, width and thickness) influence the dimensions of the selection holes at the distributors and the length and diameter of the descent systems on the seeders. These parameters, coupled with the seed kinetics, make it possible to minimize seed fractures, unseed holes and many plants on same holes (Soyoye et al.,2016).

On the other hand, unlike research geared to seed processing, very few studies have been done to the mechanization of sowing of most cereals and leguminous in Benin. Moreover, the improvement of seed varieties now makes it impossible to use the old data used in the dimensioning of the distribution components of old seeders. It is therefore necessary to characterize the seeds currently used by the producers in order to dimension the sowing equipmentand to minimize the sowing defects. Given the importance of direct sowing in water and soil conservation (Abdellaoui et al., 2011), the design of suitable equipment becomes necessary to facilitate its expansion. The present study aims to assess the physical, mechanical and kinetic characteristics of the seeds of some cereals and leguminous that are commonly cultivated in Benin with the aim to design a direct seeder in order to accompany the successful functioning of conservation agriculture. This is essential for environment preservation in the current context of climatic variability and rainfall peaks in West Africa and particularly in Benin (Perard et al., 2001; Houndénou, 1999).

\section{Material and methods}

\subsection{Plant material}

The plant material used consists of a cereal : maize (Zea mays) with two varieties (DMR ESR-W / QPM and 85 TZSR-W); four leguminous: cowpea (Vigna unguiculata) with four varieties (TVX 32-36; IT96D-610 ; IT90K-372-1-2 and IT97K-499-35), Peanut (Arachis hypogea) with a variety (TS 32-1), pigeon pea (Cajanus cajan) with local variety and soybean (Glycine max) including two varieties (Jupiter and ISRA25 / 72). These crops are retained because they are part of the main dry and oilseed crops grown in Benin (UNDP and FAO, 2000). The choice of varieties is based on their frequency on the market, revealing their degree of production.

2.2 Determination of the physical characteristics of seeds

Physical characteristics such as length, width and thickness were measured using a calipers, Kema model 150 mm in length and with an accuracy of $\pm 0.02 \mathrm{~mm}$. Data were collected on 50 seeds taken randomly from the seed lot of each variety of all species.

Arithmetic mean diameter $\left(\mathrm{D}_{\mathrm{a}}\right)$, geometric mean diameter $\left(\mathrm{D}_{\mathrm{g}}\right)$ and the sphericity $(\Phi)$ were calculated according to the following relationships (Kiani Deh Kiani et al., 2008 ; Pomeranz et al., 1985 ; Kibar and Kibar, 2017):

$$
\begin{aligned}
& D_{a}=\frac{L+W+T}{3} \\
& D_{g}=(L \times W \times T)^{\frac{1}{3}} \\
& \Phi=\frac{(L \times W \times T)^{1 / 3}}{\operatorname{Max}(L, W, T)}
\end{aligned}
$$

with L: length, W: width and T: thickness.

One of the aspect ratio $(\mathrm{R})$ is calculated using the equation of Maduako and Faborode (1990):

$$
R_{a}=\frac{L}{W}
$$

The masses were measured from an Ohaus Pioneer electronic balance and accurate $\pm 1 \mathrm{mg}$. The apparent volumes were taken using a graduated cylinder. The bulk density is calculated by:

$$
\rho_{a}=\frac{m}{v_{a}}
$$

where $\rho_{a}$ is the bulk density, $m$ mass and $v_{a}$ apparent volume. 
To assess the moisture content, a sample of 50 seeds of each variety of different species was weighed to determine the initial fresh weight $\left(\mathrm{M}_{\mathrm{f}}\right)$ using the previous electronic scale. The seeds are then dried in an oven at a temperature set at $60 \pm 2{ }^{\circ} \mathrm{C}$ during 24 hours in order to estimate the dry weight $\left(\mathrm{M}_{\mathrm{d}}\right)$. The moisture content $\left(\mathrm{W}_{\mathrm{c}}\right)$ of each sample was calculated as follows:

$$
W_{c}=\frac{M_{f}-M_{d}}{M_{d}} \times 100
$$

\subsection{Determination of mechanical characteristics}

The rupture strength was ed using the PCE-FB10k dynamometer which measuring range $10.000 \mathrm{~N}$ and precision $\pm 2 \mathrm{~N}$. A sample of 50 seeds was taken at random. Each seed was compressed in the direction of thickness. The operation is stopped when a deformation or fracture of the seed is observed (Tavakoli et al., 2009) and the maximum force applied to crush it is read on the dynamometer screen.

\subsection{Evaluation of falling speed of the seeds}

Three materials were used to characterize the seed falling speed. It is a rigid PVC tube with an external diameter of $32 \mathrm{~mm}$, a black plate (sheet steel) with $1 \mathrm{~mm}$ as thickness and a transparent hose with an external diameter of $28 \mathrm{~mm}$. The length used for each material is $500 \mathrm{~mm}$. Each material is inclined at three angles of inclination: $20^{\circ}, 50^{\circ}$ and $70^{\circ}$ relative to the vertical. The time taken by each seed to fall $50 \mathrm{~mm}$ was timed for the variety of each species depending on the materials and angle of inclination (Figure 1). The speed is obtained by the relation:

$$
V=\frac{d}{t}
$$

With $\mathrm{V}$ the falling speed of the seeds, $\mathrm{t}$ the time taken to traverse the distance $\mathrm{d}$.

\section{Statistical analysis}

An Analysis of Variance was performed on the calculated parameters. The factors studied are the dimensions, the resistance and the falling speed of the seeds. Newman and Keuls test was used for the multiple comparison of means. Pearson correlation test was performed between the dimensions of the seeds. The different analyzes and tests are carried out in the statistical software R. The differences are considered as significant at $95 \%$ confidence level $(\mathrm{p}<0.05)$.

\section{Results}

\subsection{Physical properties of seeds}

Table 1 shows the different physical parameters measured on the seeds. In general, a significant difference between the varieties of the same species is noticed, and then between the species. It noticed that the seeds have very variable formes in view of these differences in length, width and thickness. This variation in shape is higher for species showing the highest standard deviations: $A$. hypogea and $V$. unguiculata (IT96D-610) for length and the two varieties of $Z$. mays for thickness.

On the other hand, the moisture content has varied between species. The variation between the varieties of the same species isnon significant. The low moisture content is observed at Z. mays var. DMR ESR-W / QPM (3.34 $\pm 0.17 \%)$ and highest at $G$. max var. Jupiter $(7.90 \pm 2.82 \%)$. With the exception of $Z$. mays, there was a large variation in the mass between varieties of other species. However, the only variation noted in volume concerns only varieties of $V$. unguiculata(Table 1). Table 2 shows the arithmetic and geometric diameters and the sphericity of seeds. The analysis of Table 2 shows that the different diameters and coefficient varied significantly between species. However, apart from the varieties of $V$. unguiculata, the above parameters were almost unchanged between the varieties of the other seeds. Moreover, all seeds have a sphericity greater than 0.70 . The seeds of $C$. cajan is the most spherical and those of $Z$. mays the least spherical (Table 2). Table 3 shows the relationships between seed size and correlations. For almost all the seeds.The length exceeds the width which itself is greater than the thickness. The majority of the ratios is less than 2. The ratios close to 1 in case for C. cajan and G. max are a good indicator of the low variability between their dimensions. However.These ratios are more or less greater than 2 for the two varieties of Z. mays and the variety IT97K-49935 of $V$. unguiculata. On the other hand, with the exception of the varieties of $Z$. mays and A. hypogea, there are strong correlations between the dimensions of other species (Table 3 ). 
Table 1 : Mean and standard error of physical parameters per seed unit, followed by SNK test differentiation groups

\begin{tabular}{|c|c|c|c|c|c|c|c|c|}
\hline Species & Varieties & $\begin{array}{l}\text { Length } \\
(\mathrm{mm})\end{array}$ & $\begin{array}{l}\text { Width } \\
(\mathrm{mm})\end{array}$ & $\begin{array}{l}\text { Thickness } \\
\text { (mm) }\end{array}$ & $\begin{array}{c}\text { Moisture content } \\
(\%)\end{array}$ & $\begin{array}{l}\text { Mass } \\
(\mathrm{mg})\end{array}$ & $\begin{array}{l}\text { Volume } \\
\text { (ml) }\end{array}$ & $\begin{array}{l}\text { Bulk density } \\
(\mathrm{mg} / \mathrm{ml})\end{array}$ \\
\hline \multirow[b]{2}{*}{ Zea mays } & DMR ESR-W/QPM & $10.35 \pm 1.12^{\mathrm{a}}$ & $8.81 \pm 0.73^{\mathrm{a}}$ & $4.60 \pm 1.31^{c}$ & $3.34 \pm 0.17^{\mathrm{c}}$ & $279.07 \pm 8.05^{\mathrm{b}}$ & $0.53 \pm 0.0^{\mathrm{a}}$ & 527.38 \\
\hline & 85 TZSR-W & $11.31 \pm 1.44^{\mathrm{a}}$ & $9.04 \pm 0.81^{\mathrm{a}}$ & $4.87 \pm 1.1^{\mathrm{c}}$ & $3.55 \pm 0.01^{\mathrm{c}}$ & $283.31 \pm 1.17^{b}$ & $0.54 \pm 0.08^{\mathrm{a}}$ & 523.034 \\
\hline \multirow[b]{2}{*}{$\begin{array}{l}\text { Vigna } \\
\text { unguiculata }\end{array}$} & TVX 32-36 & $8.22 \pm 0.78^{\mathrm{b}}$ & $6.62 \pm 0.48^{\mathrm{c}}$ & $5.14 \pm 0.41^{\mathrm{c}}$ & $4.67 \pm 1.54^{\mathrm{abc}}$ & $134.20 \pm 4.95^{\mathrm{e}}$ & $0.24 \pm 0.0^{\mathrm{d}}$ & 571.06 \\
\hline & $\begin{array}{c}\text { IT96D-610 } \\
\text { IT90K-372-1-2 } \\
\text { IT97K-499-35 }\end{array}$ & $\begin{array}{c}8.02 \pm 1.69^{\mathrm{b}} \\
10.36 \pm 1.28^{\mathrm{a}} \\
9.71 \pm 1.32^{\mathrm{a}}\end{array}$ & $\begin{array}{l}6.68 \pm 0.87^{\mathrm{c}} \\
7.69 \pm 0.78^{\mathrm{b}} \\
6.81 \pm 0.64^{\mathrm{c}}\end{array}$ & $\begin{array}{l}4.67 \pm 0.43^{\mathrm{c}} \\
6.16 \pm 0.74^{\mathrm{b}} \\
4.92 \pm 0.70^{\mathrm{c}}\end{array}$ & $\begin{array}{l}7.46 \pm 0.02^{\mathrm{ab}} \\
6.65 \pm 0.07^{\mathrm{abc}} \\
7.48 \pm 0.05^{\mathrm{ab}}\end{array}$ & $\begin{array}{c}135.76 \pm 2.15^{\mathrm{e}} \\
210.49 \pm 13.36^{\mathrm{c}} \\
172.44 \pm 3.68^{\mathrm{d}}\end{array}$ & $\begin{array}{l}0.26 \pm 0.01^{\mathrm{d}} \\
0.44 \pm 0.0^{\mathrm{b}} \\
0.35 \pm 0.05^{\mathrm{c}}\end{array}$ & $\begin{array}{l}517.63 \\
478.39 \\
492.68\end{array}$ \\
\hline $\begin{array}{l}\text { Arachis } \\
\text { hypogea }\end{array}$ & TS 32-1 & $10.54 \pm 2.95^{\mathrm{a}}$ & $6.72 \pm 0.58^{c}$ & $7.21 \pm 0.81^{\mathrm{a}}$ & $4.36 \pm 0.04^{\mathrm{abc}}$ & $308.0 \pm 0.54^{\mathrm{a}}$ & $0.58 \pm 0.04^{\mathrm{a}}$ & 535.65 \\
\hline Cajanus cajan & Local variety & $5.84 \pm 0.43^{\mathrm{d}}$ & $5.86 \pm 0.52^{d}$ & $4.6 \pm 0.39^{c}$ & $5.99 \pm 0.62^{\mathrm{abc}}$ & $102.49 \pm 3.75^{\mathrm{g}}$ & $0.17 \pm 0.0^{\mathrm{d}}$ & 597.28 \\
\hline Glycine max & $\begin{array}{c}\text { Jupiter } \\
\text { ISRA25/72 } \\
\end{array}$ & $\begin{array}{c}6.98 \pm 0.41^{\mathrm{bcd}} \\
6.20 \pm 0.54^{\mathrm{cd}}\end{array}$ & $\begin{array}{l}5.87 \pm 0.52^{\mathrm{d}} \\
5.68 \pm 0.42^{\mathrm{d}}\end{array}$ & $\begin{array}{l}4.70 \pm 0.37^{\mathrm{c}} \\
4.22 \pm 0.56^{\mathrm{c}}\end{array}$ & $\begin{array}{l}7.90 \pm 2.82^{\mathrm{a}} \\
4.92 \pm 0.08^{\mathrm{abc}}\end{array}$ & $\begin{array}{c}122.39 \pm 1.03^{\mathrm{ef}} \\
97.34 \pm 1.04^{\mathrm{g}}\end{array}$ & $\begin{array}{l}0.20 \pm 0.0^{\mathrm{d}} \\
0.2 \pm 0.04^{\mathrm{d}}\end{array}$ & $\begin{array}{l}624.97 \\
486.70\end{array}$ \\
\hline
\end{tabular}

In a column, the means with different letters are significantly different ( $\mathrm{p}<0.001)$ according to Newman and Keuls test. 
Table 2 : Mean and standard error of seed form parameters followed by SNK test differentiation groups

\begin{tabular}{llccc}
\hline Species & Varieties & $\begin{array}{c}\text { Arithmetic diameter } \\
(\mathrm{mm})\end{array}$ & $\begin{array}{c}\text { Geometric diameter } \\
(\mathrm{mm})\end{array}$ & Sphericity \\
\hline Zea mays & DMR ESR-W/QPM & $7.92 \pm 0.52^{\mathrm{a}}$ & $7.41 \pm 0.60^{\mathrm{ab}}$ & $0.72 \pm 0.10^{\mathrm{c}}$ \\
& 85 TZSR-W & $8.41 \pm 0.52^{\mathrm{a}}$ & $7.87 \pm 0.62^{\mathrm{a}}$ & $0.71 \pm 0.11^{\mathrm{c}}$ \\
Vigna unguiculata & TVX 32-36 & $6.66 \pm 0.48^{\mathrm{b}}$ & $6.53 \pm 0.46^{\mathrm{c}}$ & $0.80 \pm 0.04^{\mathrm{bc}}$ \\
& IT96D-610 & $6.46 \pm 0.96^{\mathrm{bc}}$ & $6.29 \pm 0.88^{\mathrm{cd}}$ & $0.80 \pm 0.08^{\mathrm{bc}}$ \\
& IT90K-372-1-2 & $8.07 \pm 0.88^{\mathrm{a}}$ & $7.88 \pm 0.85^{\mathrm{a}}$ & $0.76 \pm 0.03^{\mathrm{bc}}$ \\
Arachis hypogea & TT97K-499-35 & $7.15 \pm 0.81^{\mathrm{b}}$ & $6.87 \pm 0.78^{\mathrm{bc}}$ & $0.71 \pm 0.05^{\mathrm{c}}$ \\
Cajanus cajan & Local variety & $8.16 \pm 1.30^{\mathrm{a}}$ & $7.94 \pm 1.13^{\mathrm{a}}$ & $0.78 \pm 0.13^{\mathrm{bc}}$ \\
Glycine max & Jupiter & $5.43 \pm 0.40^{\mathrm{d}}$ & $5.39 \pm 0.40^{\mathrm{e}}$ & $0.91 \pm 0.03^{\mathrm{a}}$ \\
& ISRA25/72 & $5.85 \pm 0.38^{\mathrm{cd}}$ & $5.77 \pm 0.39^{\mathrm{de}}$ & $0.83 \pm 0.03^{\mathrm{b}}$ \\
\hline
\end{tabular}

In a column, the means with different letters are significantly different $(\mathrm{p}<0.001)$ according to Newman and Keuls test.

Table 3 : Relationship between seed size andcorrelations

\begin{tabular}{|c|c|c|c|c|}
\hline \multirow[t]{2}{*}{ 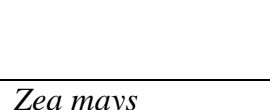 } & \multirow[t]{2}{*}{ Varieties } & \multicolumn{3}{|c|}{ Ratio } \\
\hline & & $\mathrm{L} / \mathrm{W}$ & $\mathrm{L} / \mathrm{T}$ & $\mathrm{W} / \mathrm{T}$ \\
\hline \multirow[t]{2}{*}{ Zea mays } & DMR ESR-W/QPM & $\begin{array}{c}1.18 \pm 0.13 \\
(0.35)^{\mathrm{NS}}\end{array}$ & $\begin{array}{c}2.40 \pm 0.65 \\
(-0.44)^{\mathrm{NS}}\end{array}$ & $\begin{array}{c}2.03 \pm 0.48 \\
(-0.18)^{\mathrm{NS}}\end{array}$ \\
\hline & 85 TZSR-W & $\begin{array}{c}1.27 \pm 0.24 \\
(-0.46)^{\mathrm{NS}}\end{array}$ & $\begin{array}{c}2.44 \pm 0.67 \\
(-0.10)^{\mathrm{NS}}\end{array}$ & $\begin{array}{c}1.90 \pm 0.24 \\
(0.79)^{* *}\end{array}$ \\
\hline \multirow[t]{4}{*}{ Vigna unguiculata } & TVX 32-36 & $\begin{array}{c}1.24 \pm 0.08 \\
(0.77)^{* * *}\end{array}$ & $\begin{array}{c}1.61 \pm 0.17 \\
(0.36)^{\mathrm{NS}}\end{array}$ & $\begin{array}{c}1.29 \pm 0.09 \\
(0.63)^{*}\end{array}$ \\
\hline & IT96D-610 & $\begin{array}{c}1.19 \pm 0.13 \\
(0.91)^{* * * * *}\end{array}$ & $\begin{array}{c}1.71 \pm 0.26 \\
(0.81)^{* *}\end{array}$ & $\begin{array}{c}1.43 \pm 0.08 \\
(0.94)^{* * * *}\end{array}$ \\
\hline & IT90K-372-1-2 & $\begin{array}{c}1.35 \pm 0.12 \\
(0.69)^{*}\end{array}$ & $\begin{array}{l}1.68 \pm 0.08 \\
(0.94)^{* * * *}\end{array}$ & $\begin{array}{c}1.25 \pm 0.09 \\
(0.80)^{* *}\end{array}$ \\
\hline & IT97K-499-35 & $\begin{array}{c}1.42 \pm 0.12 \\
(0.82)^{* *}\end{array}$ & $\begin{array}{c}1.98 \pm 0.24 \\
(0.69)^{*}\end{array}$ & $\begin{array}{c}1.40 \pm 0.13 \\
(0.72)^{*}\end{array}$ \\
\hline Arachis hypogea & TS 32-1 & $\begin{array}{c}1.56 \pm 0.38 \\
(0.51)^{\mathrm{NS}}\end{array}$ & $\begin{array}{c}1.45 \pm 0.33 \\
(0.60)^{\mathrm{NS}}\end{array}$ & $\begin{array}{c}0.94 \pm 0.05 \\
(0.88)^{* * * *}\end{array}$ \\
\hline Cajanus cajan & Local variety & $\begin{array}{c}1.00 \pm 0.07 \\
(0.68)^{*}\end{array}$ & $\begin{array}{c}1.27 \pm 0.08 \\
(0.67)^{*}\end{array}$ & $\begin{array}{c}1.27 \pm 0.07 \\
(0.82)^{* * *}\end{array}$ \\
\hline \multirow[t]{2}{*}{ Glycine $\max$} & Jupiter & $\begin{array}{c}1.20 \pm 0.09 \\
(0.49)^{\mathrm{NS}}\end{array}$ & $\begin{array}{c}1.49 \pm 0.08 \\
(0.80)^{* *}\end{array}$ & $\begin{array}{c}1.25 \pm 0.07 \\
(0.75)^{*}\end{array}$ \\
\hline & ISRA25/72 & $\begin{array}{c}1.09 \pm 0.05 \\
(0.84)^{* * *}\end{array}$ & $\begin{array}{c}1.48 \pm 0.12 \\
(0.87)^{* * * *}\end{array}$ & $\begin{array}{c}1.36 \pm 0.12 \\
(0.88)^{* * * *}\end{array}$ \\
\hline
\end{tabular}

Each number in parenthesis is the correlation value between the two parameters. NS: Not significant at $95 \%$ confidence level $(\mathrm{p}>0.05) .{ }^{*}$ significant at $95 \%(\mathrm{p}<0.05) .{ }^{* *}$ significant at $99 \%(\mathrm{p}<0.01) .{ }^{* * *}$ significant at $99.9 \%$ $(\mathrm{p}<0.001)$ based on Pearson correlation test.

4.2 Mechanical seed property

Table 4 summarizes the fracture force of each seed. Table 4 shows that the rupture effort varied greatly between the majority of the varieties of species and then of one species to another. The minimum breakdown stress varies from $14 \mathrm{~N}$ for $A$. hypogea TS $32-1$ to $580 \mathrm{~N}$ for $V$. unguiculata TVX 32-36. The maximum force varie from $18 \mathrm{~N}$ to $720 \mathrm{~N}$ respectively for the same varieties. V. unguiculata TVX $32-36$ is the most resistant $(633.3 \pm 75.72 \mathrm{~N})$ against A. hypogea TS 32-1 least resistant of fracture $(16.0 \pm 2.0 \mathrm{~N})$ (Table 4).

\subsection{Seed kinetics}

Figure 1 shows the evolution of falling speed of the seeds as a function of the type of material and the angles of inclination. The analysis of variance revealed a significant difference between speeds according to the type of material and the angle of inclination for each variety of species on the one hand; and between the varieties then the species on the other hand $(\mathrm{p}=0.000)$. For all varieties, falling speeds decrease as the angle of inclination increases. These speeds are zero at $70^{\circ}$ inclination on the PVC for all Z. mays and V. unguiculata; on the black sheet for Z. mays and on the transparent hosefor the DMR ESR-W / QPM variety of Z. mays and the variety IT97K-499-35 of $V$. unguiculata (Figure 1). 
Table 4 : Rupture efforts perseed

\begin{tabular}{llccc}
\hline & Varieties & $\begin{array}{c}\text { Minimum fracture } \\
\text { force }(\mathrm{N})\end{array}$ & $\begin{array}{c}\text { Maximum } \\
\text { fracture force }(\mathrm{N})\end{array}$ & $\begin{array}{c}\text { Average of fracture } \\
\text { force }(\mathrm{N})\end{array}$ \\
\hline Zea mays & DMR ESR-W/QPM & 290 & 362 & $319.3 \pm 37.81^{\mathrm{b}}$ \\
& 85 TZSR-W & 237 & 270 & $253.0 \pm 16.52^{\mathrm{c}}$ \\
Vigna unguiculata & TVX 32-36 & 580 & 720 & $633.3 \pm 75.72^{\mathrm{a}}$ \\
& IT96D-610 & 115 & 132 & $122.3 \pm 8.74^{\mathrm{de}}$ \\
& IT90K-372-1-2 & 56 & 80 & $69.33 \pm 12.22^{\mathrm{e}}$ \\
Arachis hypogea & IT97K-499-35 & 112 & 160 & $132.0 \pm 24.98^{\mathrm{de}}$ \\
Cajanus cajan & TS 32-1 & 14 & 18 & $16.0 \pm 2.0^{\mathrm{f}}$ \\
Glycine max & Local variety & 140 & 170 & $154.0 \pm 15.1^{\mathrm{d}}$ \\
& Jupiter & 94 & 124 & $104.0 \pm 17.32^{\mathrm{de}}$ \\
\hline
\end{tabular}

Means with different letters are significantly different $(\mathrm{p}<0.001)$ according to Newman and Keuls test.

\section{Discussion}

5.1 Physical properties of seeds

The three dimensions of all seeds species (length. width and thickness) differ clearly and in decreasing order from length, width to thickness except for C. cajan (Table 1). The dimensions obtained on maize are closer to those obtained by Tarighi et al. (2011) which are respectively L: $11.33 \pm 0.49 \mathrm{~mm}, \mathrm{~W}: 7.93 \pm 0.55 \mathrm{~mm}, \mathrm{~T}: 4.69$ \pm 0.33 mmat $5.15 \%$ moisture of $Z$. mays yellow variety similar to 85 TZSR-W. The sphericity of maize obtained in this study ( 0.71 to 0.72 ) at 3.44 to 3.55 as moisture content are higher than those obtained by Ashwin Kumar et al. (2017) which increased from 0.63 to 0.67 as the moisture content increased from 12 to $20 \%$.

For the varieties of $V$. unguiculata, the normal dimensions vary as follows: L: 6-10 mm, W: 4-7 mm and T: 3-5 $\mathrm{mm}$ (Henshaw, 2008); comparable to the results of this study with the exception of the variety IT90K-372-1-2 where the thickness is $6.16 \pm 0.74 \mathrm{~mm}$. The results about $G$. max are also close to those obtained by Kibar and Öztürk (2008) where L: $7.32 \pm 0.39 \mathrm{~mm}, \mathrm{~W}: 6.79 \pm 0.41 \mathrm{~mm}, \mathrm{~T}: 5.78 \pm 0.34 \mathrm{~mm}, \mathrm{D}_{\mathrm{a}}: 6.60 \mathrm{~mm}$ and $\mathrm{D}_{\mathrm{g}}: 6.57$ $\mathrm{mm}$. However, overall the variability of seed length appears to be greater than that of width and thickness given the standard deviations. Kibar (2016) obtained different grain moisture contents for corn grains at different storage times, which are close to the results of this study. The mean arithmetic diameters of varieties of $V$. unguiculata IAR-339-1; V. unguiculataIT86D-1010 and Ife brown increased respectively from 7.84 to 10.08 $\mathrm{mm} ; 9.14$ to $11.52 \mathrm{~mm}$ and 7.69 to $9.87 \mathrm{~mm}$ (Arthur, 2009); with geometric diameters always less than the arithmetic diameters. These values are superior to the results of this study with a compliance with the relationship between the two diameters. The high coefficient of variation of the thickness led Bockstaller (1993) to use the thickness instead of sphericity as a criterion to sort the seeds according to the form. This sphericity (Table 2) previously used by Pomeranz et al. (1985) to characterize the form is based on the assumption that the grain is an ellipsoid of maximum length $\mathrm{L}$, width $\mathrm{W}$ and thickness $\mathrm{T}$ and that this coefficient would be equal to 1 if the grain was a perfect sphere.Generally, the sphericity depend of moisture content and there is an increasing trends for sphericity with moisture content (Barnwal et al., 2012).Because the real form of the seeds is in some cases similar to a prism (Z. mays), in other cases a sphere (C. cajan and G. max) and with all intermediates and irregular forms ( $V$. unguiculata and A. hypogea), there is no direct link between the sizing of cereals and leguminous studied. This makes to think of a conception of specific distribution system to each species.

However, an approximation of the dimensions of certain varieties and / or species would make it possible to overcome this obstacle and to design a distributor for varieties and species with similar characteristics. Moreover, these dimensions increase with the increase in the moisture content of the seeds (Davies and Zibokere, 2011). This is what Henshaw, (2008) found with Z. mays var. IAR-339-1 whose length increased by $87 \%(9.80$ to $13 \mathrm{~mm}$ ) and $74 \%$ (12 to $15 \mathrm{~mm}$ ) for $V$. unguiculata var. IT86D-1010. An average sphericity value greater than 0.78 is a good value for sowing results (Tits and Leveque, 2001). For almost all seeds, the ratios (L / $\mathrm{W} ; \mathrm{L} / \mathrm{T}$ and $\mathrm{W} / \mathrm{T}$ ) are less than 2 (Table 3). This means that if we use the largest dimension of the seed to design the hole of distribution system there is less risk for doubloon. However, these ratios are greater than 2 for the two varieties of $Z$. mays and the variety IT97K-499-35 of $V$. unguiculata if we account their standard error. This suggests the risk of selecting two seeds when sowing. On the other hand, with the exception of the varieties of $Z$. mays and A. hypogea, there are strong correlations between the dimensions of other species.

The calibration based on the passage of the grains by grids with holes of variable size and form is the method used in seed production. However, this method used by many authors does not suggest any connection between size and real seed size and merit a reflection (Bockstaller, 1993). 

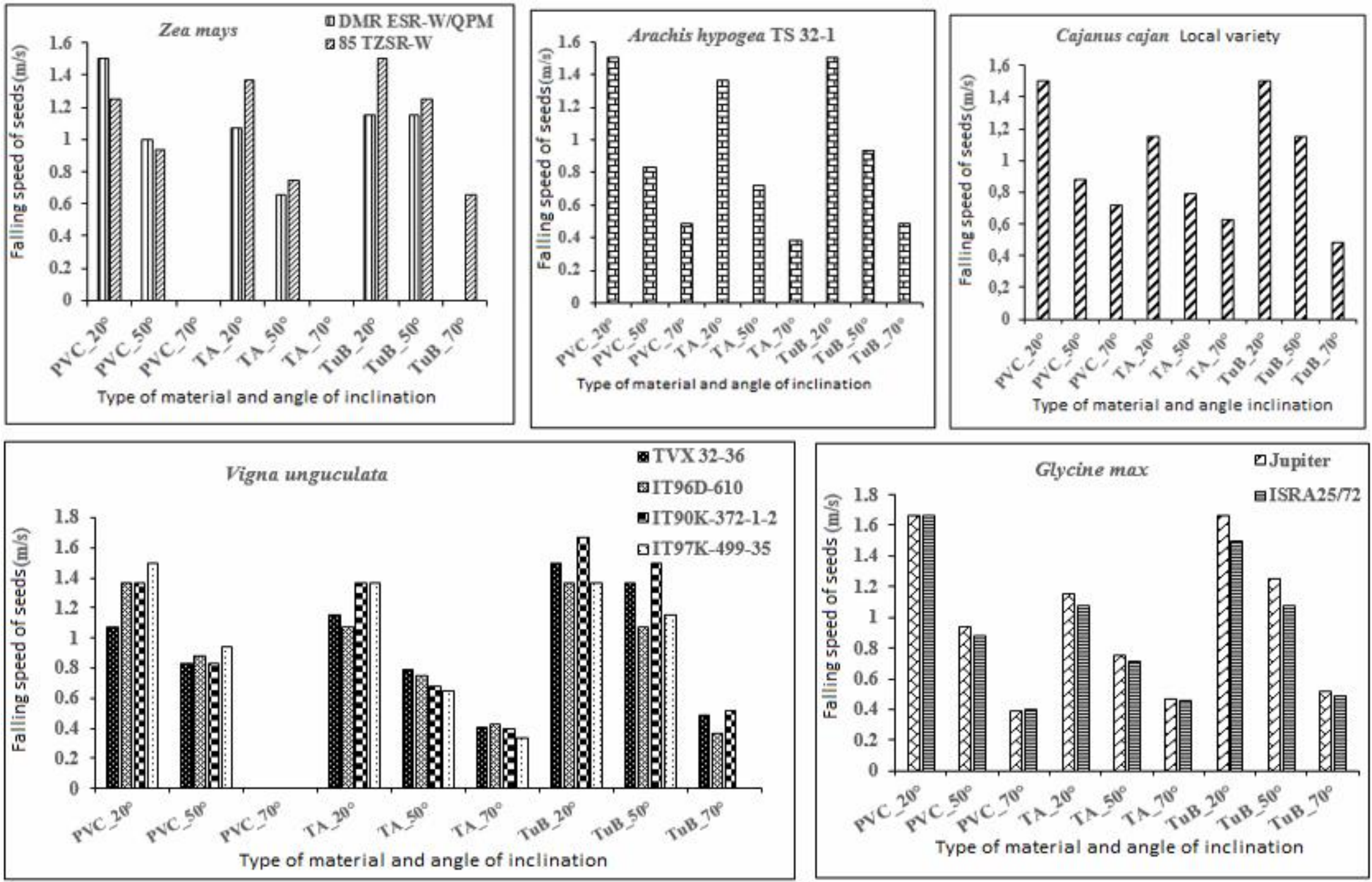

Fig. 1 Seed falling speed according to material type and angle of inclination

Legend : PVC_20 : rigid PVC tube inclined at $20^{\circ}$; TA_20 
For the same author, two extreme and theoretical cases make it possible to approach the notion of caliber: if all the grains were of spherical or cylindrical form, the caliber would be defined by the diameter of the hole corresponding to maximum diameter of the seeds which can pass through the grid. For this purpose, a single measurable criterion, in this case the diameter, would be sufficient to define the size. But if it is a parallelepipedic form, the grain can then cross the grid only by appearing in front of the hole by its smallest surface (Bockstaller. 1993). This is not that simple. Tests based on the efficiency of seed selection with distributors sized according to length, width, thickness, arithmetic diameter or geometry by varieties and species are required. This must be based on the present results relating to these parameters.

\subsection{Mechanical property of seeds}

The fracture forces varied greatly between the majority of the varieties of species and then of species to another (Table 4). The fracture stress along the thickness decreases from 347.5 to $226.2 \mathrm{~N}$ for $Z$. mays when its moisture content increases from 5.15 to 22\% (Tarighi et al., 2011). This is same thingwith in this study. As regards $V$. unguiculata, Henshaw (2008) found a rupture force ranging from 60 to $80 \mathrm{~N}$. This is not verified in this studyexcept for the variety IT90K-372-1-2 for which this force ranged from 56 to $80 \mathrm{~N}$. It may be related to the moisture content which varied between the most resistant variety $(4.67 \pm 1.54 \%)$ and the least resistant to fracture $(6.65 \pm 007 \%)$. This is harmony with Obi et al. (2014) which reported a inversely proportional relationship between the fracture force and the moisture content which ranged successively from 159.10 to $69.30 \mathrm{~N}$ and $10 \%$ to $25 \%$ for $C$. cajan. According to the same authors, this would result from the fact that the seed of $C$. cajan would have a soft texture when its moisture content is high.Davies and Zibokere, (2011) found that the fracture forces ranges from 64 ti $40 \mathrm{~N}$ for IAR-339-1, 63 to 38 $\mathrm{N}$ for IT86D-1010 and 70 to $46 \mathrm{~N}$ for Ife Brown, and they conclued that the decrease observed from fracture force at higher moisture content showed that cowpea is sensitive to moisture content.

Moreover, the seed form has an influence on their mechanical strength. Indeed, grain breakage is favored by the angularity of the particles. Grain fracture increases with angularity for granitic gravel after a triaxial test (Ovalle, 2013). This is due to the fact that the angular grains have fewer points of contact between particles and therefore transmit higher forces with respect to rounded grains under the same macro-mechanical stress. Similarly, geometric irregularities or angular grain tips are more sensitive to fractures and attrition.

\subsection{Seed kinetics}

As the angle of inclination increases, the falling speedof seeds decrease depending on the type of material and the angle of inclination for each variety of each species (Figure 1). The ideal would be to have a high speed for a fast fall of seeds. However, the positioning of the descent tubes between the hopper and the opening systems is not always linear. The descent is more rapid firstly for the transparent hose followed by the rigid PVC. These speeds are even zero at $70^{\circ}$ inclination on all materials for some species. This reveals the margins to be observed in the inclination of the tubes and also raises the problem of the friction coefficient of the seeds on the walls of the tubes. These parameters make it possible to determine the ideal length and the adequate angle of inclination of the seed descent channels for an accurate fall of the seeds in the bottom of the seed bed.

\section{Conclusion}

The present study on the characterization of seeds made it possible to assess the physical, mechanical and kinetic properties of the most cultivated cereals and legumous in Benin. This work shows that for most of the studied seeds the lengths are greater than the widths which themselves exceed the thicknesses. The sphericity are greater than 0.7 with more ratios less than 2 except forZea mays varieties. The fracture forces varies from 14 to $720 \mathrm{~N}$ with the varieties of Vigna as the most resistant and Arachis hypogea the least resistant. The falling speed depends on the type of material and generally decreases from 1.67 to $0 \mathrm{~m} / \mathrm{s}$ as the angle of inclination increases from $20^{\circ}$ to $70^{\circ}$ relative to vertical. Based on the results of this study, different distribution organs can be fabricatedwith a certain number of varieties and / or species. A good design of a seeder remains subject to the knowledge of these parameters. These parameters are also essential for other use needing grain size, grain calibration and other use in agricultural engineering and food processing.

\section{Acknowledgement}

This research was supported by the International Foundation for Science, Sweden, through a research grant to DAYOU Ephrème Dossavi.

\section{References}

Abdellaoui Z., Zaghouane O., Belhadj A., Teskrat H. 2011. Etude comparative de l'effet du travail conventionnel, semis direct et travail minimum sur le comportement d'une culture de blé dur dans la zone subhumide. In: Bouzerzour H. (ed.), Irekti H. (ed.), Vadon B. (ed.). 4. Rencontres Méditerranéennes du Semis Direct. Zaragoza : CIHEAM / ATU-PAM / INRAA/ ITGC/FERT, 2011. p71-87 (Options Méditerranéennes : Série A. Séminaires Méditerranéens; n. 96). 
Achigan-Dako E. G., Houdegbe A. C., Glèlè M. et Nono-Womdim R. 2014. Analyse du système de production et de distribution des semences de maïs (Zea mays L.) au Sud-Bénin. Biotechnologie, Agronomie, Société et Environnement, Vol. 18, No. 1, pp. $49-60$.

Ahouansou R. H., Aïssi M. V., Sanya E. A. et Soumanou M. M. 2012. Propriétés physique et mécanique des graines de Pentadesma butyracea produites au Bénin. Journal of Applied Biosciences Vol. 50, pp. 3485- 3493.

Arthur M.A. 2009. Moisture-dependent physical properties of Cowpea. Unpublished B.Sc. Thesis, Department of Agricultural and Environmental Engineering, Niger Delta University, Bayelsa State. 64pp.

Ashwin kumar B., Rao P.V. K. J. and Edukondalu L. 2017. Physical properties of maize grains. International Journal of Agriculture Sciences, Vol. 9, No. 27, pp. 4338-4341.

Azmon H. B. 2013. Mechanical seed: dispensing machine for the vegetable industry. Feature. Jurutera, 31-33.

Barnwal P., Kadam D. M. and. Singh K. K. 2012. Influence of moisture content on physical properties of maize. International Agrophysics, Vol. 26, pp. 331-334.

Bockstaller C. 1993. Taille et forme des semences de maïs (zea mays L.) : variabilité et effets sur la croissance, le développement et le rendement. Thèse pour l'obtention du titre de Docteur en Sciences Agronomiques. Institut national polytechnique de lorraine. $227 \mathrm{p}$.

Davies R. M. and Zibokere D. S. 2011. Effect of Moisture Content on Some physical and mechanical Properties of Three Varieties of Cowpea (Vigna unguiculata (L) Walp). Agricultural Engineering International: CIGR Journal, Manuscript No.1700. Vol. 13, No.1.

Faleye T., Atere O. A., Oladipo O. N. and Agaja M. O. 2013. Determination of some physical and mechanical properties of some cowpea varieties. Short Communication. African Journal of Agricultural Research. Vol. 8, No. 49, pp. 6485-6487.

FAO, 2015. Division des statistiques de la FAO 2015, FAOSTAT, 4 Octobre 2015.

Henshaw F.O. 2008. Varietal differences in physical and proximate composition of Cowpea (Vigna unguiculata). World Journal of Agricultural Sciences, Vol. 4, No. 3, pp. 302-306.

Houndénou C. 1999. Variabilité climatique et maïsiculture en milieu tropical humide : exemple du Bénin, diagnostic et modélisation. Thèse de doctorat de géographie. UMR 5080, CNRS «climatologie de l'espace tropical », Université de Bourgogne, Centre de recherche de climatologie, 341p.

IRAD, 2013. Contribution de la recherche à l'amélioration de la production et la consommation des légumineuses alimentaires au Caméroun. Projet 6 : Légumes. 57p.

Kiani Deh Kiani M., Minaei S., Maghsoudi H. and Ghasemi Varnamkhasti M. 2008. Moisture dependent physical properties of red bean (Phaseolus vulgaris L) grains. International Agrophysics, Vol. 22, pp. 231-237.

Kibar H. and Öztürk T. 2008. Physical and mechanical properties of soybean. International Agrophysics, Vol. 22, pp. 239-244.

Kibar H. 2016. Determining the functional characteristics of wheat and corn grains depending on storage time and temperature. Journal of Food Processing and Preservation, Vol. 40, pp. 749-759.

Kibar B. and Kibar H. 2017. Determination of the nutritional and seed properties of some wild edible plants consumed as vegetable in the Middle Black Sea Region of Turkey. South African Journal of Botany, Vol. 108, pp. 117-125.

Macauley H. et Ramadjita T. 2015. Les cultures céréalières: riz, maïs, millet, sorgho et blé. Document de reference. Centre international de conferences Abdou Diouf, Dakar, Sénégal. 38p.

Maduako J.N. and M.O. Faborode, 1990. Some physical properties of cocoa pods in relation to primary processing. Ife. Journal of Technology, Vol. 2, pp. 1-7.

Massicotte D., Denis J. et Lamarre G. 2000. Guide des pratiques de conservation en grande culture. Conseil des productions végétables du Québec inc. $17 \mathrm{p}$.

Obi O. F., Anyadike C. C. and Onyeke C. O. 2014. Moisture-dependent mechanical properties of pigeon pea grown in Nigeria. International Journal of Science, Environment and Technology, Vol. 3, No 3, pp. 966 - 975.

Pérard J., Boko M., Houndenou C. et Hernandez K. 2001. Mise en évidence du rôle des «précipitations tardives» dans la variabilité pluviométrique du bassin béninois du Niger (Afrique de l'Ouest). Publications de l'Association Internationale de Climatologie, Vol. 14, pp. 127-133.

PNUD et FAO, 2000. Assistance à l'élaboration d'un schéma directeur du secteur de développement agricole et rural. Rapport préliminaire du sous - secteur des cultures vivrières. Cotonou. 69p.

Pokhrel S. and Pokhrel S. 2013. Legumes crop rotation can improve food and nutrition security in Nepal. Agronomy Journal of Nepal (Agron JN) Vol. 3, pp. 123-127.

Pomeranz Y., Czuchajowska Z., Martin C.R. and Lai F. S. 1985. Détermination of corn hardness by the stenvert hardness tester. Cereal Chemistry, Vol. 62, pp. 108-112.

Raunet M. 2002. Projet de recherche-développement sur le semis direct avec couverture végétale en Tunisie. Contexte et propositions d'appuis scientifiques. P.12.

Soyoye, B. O., Ademosun O. C. and Olu-Ojo E. O. 2016. Manually operated vertical seed-plate maize planter. Agricultural Engineering International: CIGR Journal, Vol. 18, No.4, pp. 70-80. 
Tarighi J., Mahmoudi A. and Alavi N. 2011. Some mechanical and physical properties of corn seed (Var. DCC 370). African Journal of Agricultural Research Vol. 6, No. 16, pp. 3691-3699.

Tavakoli H., Rajabipour A., and Mohtasebi S.S. 2009. Moisture-dependent some engineering properties of Glycine max grains". Agricultural Engineering International: the CIGR Ejournal. Manuscript 1110. Vol. XI.

Tits M. et Leveque E. 2001. Caractéristiques physiques de lots de graines : Etude comparative de protocoles de mesures et leurs relations avec la semabilité observée au banc d'essais de semoirs regroupant onze laboratoires. Proceedings of the 64th IIRB Congress, Bruges (B).

\section{Biographical notes}

E. D. Dayou and K. L. B. Zokpodo, are of the School of Environmental Management and Management, Faculty of Agronomic Sciences, University of AbomeyCalavi 01 BP 526 Cotonou, Benin

A. L. R. Glele Kakaï is of the laboratory of Biomathematics and Forestry Estimations, Faculty of Agronomic Sciences, University of Abomey-Calavi 04 BP 1525 Cotonou, Benin

Received September 2018

Accepted November 2018

Final acceptance in revised form November 2018 